DOI: https://doi.org/10.24127/ajpm.v10i4.4194

\title{
DESKRIPSI KEMAMPUAN BERPIKIR KREATIF MATEMATIS DITINJAU DARI RESILIENSI MATEMATIS SISWA DALAM PEMBELAJARAN TATAP MUKA TERBATAS
}

\author{
M. Agung Dharma Himawan', Sri Hastuti Noer² \\ ${ }^{1,2}$ Universitas Lampung, Bandar Lampung, Indonesia \\ *Corresponding author. Universitas Lampung, Bandar Lampung, Indonesia \\ E-mail: $\quad$ agungdharmahimawan@gmail.com ${ }^{1)}$ \\ hastuti_noer@yahoo.com $^{2)}$
}

Received 04 September 2021; Received in revised form 04 December 2021; Accepted 22 December 2021

\begin{abstract}
Abstrak
Tujuan dilakukan penelitian ini adalah mendeskripsikan kondisi kemampuan berpikir kreatif siswa jika ditinjau berdasarkan tingkat resiliensi yang dimiliki oleh siswa. Penelitian ini didasari oleh adanya dampak perubahan pola belajar siswa karena pandemi covid-19. Kemapuan memberikan ide yang tidak umum dan hanya digunakan oleh beberapa orang tertentu untuk menyelesaikan masalah matematika disebut dengan kemampuan berpikir kreatif. Terdapat empat indikator siswa dikatakan kreatif diantaranya adalah kelancaran, keluwesan, orisinalitas, dan kemampuan memerinci. Resiliensi matematis siswa adalah kegigihan siswa dalam menghadapi permasalahan dalam pembelajaran matemtika. Metode yang digunakan adalah metode kualitatif dengan tujuan untuk mendapatkan gambaran secara menyeluruh terkait kemampuan berpikir kreatif tingkat resiliensi siswa secara lebih mendalam. 30 siswa kelas VII A SMP Negeri 1 Batu Ketulis, Lampung Barat Tahun Pelajaran 2020/2021 merupakan sampel yang diambil kemudian direduksi menjadi 6 siswa dengan menggunakan teknik pengambilan sampel didasarkan oleh pertimbagan tertentu. Data dikumpulkan dengan memberikan kuisioner, soal materi bangun datar, dan wawancara. Instrumen yang digunakan berupa angket kemampuan resiliensi matematis siswa, tes uraian pada materi segi empat (bangun datar), dan pedoman wawancara. Kesimpulan yang diperoleh adalah indikator kelancaran dan keterincian sering muncul pada siswa dengan tingkat resiliensi tinggi, indikator kelancaran muncul pada siswa yang memiliki resiliensi sedang sedang, dan siswa dengan tingkat resiliensi rendah belum mampu memunculkan satupun indikator berpikir kreatif.
\end{abstract}

Kata kunci: Berpikir kreatif; resiliensi matematis.

\begin{abstract}
The purpose of this research is to describe condition of students' creative thinking skills when viewed based on the level of resilience possessed by students. This research is based on the impact of changes in student learning patterns due to the COVID-19 pandemic. The ability to provide ideas that are not common and only used by certain people to solve mathematical problems is called the ability to think creatively. There are four indicators that students are said to be creative including fluency, flexibility, originality, and elaboration. Students' mathematical resilience is the persistence of students in dealing with problems in learning mathematics. The method used is a qualitative method with the aim of getting a comprehensive picture of students' creative thinking skills at the level of resilience in more depth. 30 students of class VII A Junior High School 1 Batu Ketulis, West Lampung in the 2020/2021 academic year are samples taken and then reduced to 6 students with using a sampling technique based on certain considerations. Data was collected by giving questionnaires, questions about data building materials, and interviews. The instrument used was a questionnaire on students' mathematical resilience abilities, a description of the rectangular material description (data structure), and interview guidelines. The conclusion obtained is that indicators of medium and detail often appear in students with high levels of resilience, indicators appear in students who have resilience, and students with low levels of resilience have not been able to bring up indicators of creative thinking.
\end{abstract}

Keywords: Creatif thinking; mathematical resilience. 
DOI: https://doi.org/10.24127/ajpm.v10i4.4194

\section{PENDAHULUAN}

Pembelajaran saat ini menuntut siswa untuk menguasai berbagai kompetensi yang diperlukan dalam kehidupan sehari-hari. Salah satu kemampaun yang sangat berguna untuk dimiliki oleh siswa adalah kemampuan berpikir kreatif. Namun, pandemi covid19 membuat perubahan yang sangat besar terutama dalam sistem pendidikan di negara Indonesia. Pola pembelajaran berubah, mulai dari pembelajaran tatap muka biasa menjadi pembelajaran daring, lalu berubah kembali menjadi pembelajaran tatap muka terbatas. Menurut (Kemendikbud, 2021), pemerintah daerah wajib menerapkan proses pembelajaran dengan mengurangi jumlah siswa dalam suatu kelas dan mewajibkan guru dan tenaga pendidikan untuk melakukan vaksinasi. Namun, banyak permasalahan yang dialami oleh siswa selama pembelajaran tatap muka terbatas, salah satunya adalah jumlah jam pembelajaran yang relatif singkat. Menurut (Kemendikbud, 2021), aturan jumlah maksimal siswa perkelas adalah 18 orang untuk jenjang SMP dengan jumlah jam pelajaran berkisar antara 2,5 sampai dengan 3 jam perhari. Walaupun jumlah jam pembelajaran sangat terbatas, tidak sedikit siswa yang mampu mencapai prestasi akademik cukup tinggi saat pandemi covid 19.

Berdasarkan hasil penilaian harian, sebanyak 56,6\% dari jumlah siswa lulus dengan nilai ketuntasan minimum yaitu 70 dan 13,3\% siswa memiliki nilai dengan kategori sangat baik yaitu di atas 90. Hal tersebut menandakan bahwa tidak semua siswa mengalami hambatan saat pandemi. Meskipun nilai yang diperoleh siswa tergolong baik, berdasarkan hasil wawancara sebagian besar siswa masih merasa kesulitan saat diberikan soal yang menuntut banyak jawaban. Siswa cenderung hanya dapat memberikan satu jawaban dengan menggunakan cara yang sudah diajarkan oleh guru.

Kemampuan untuk bertahan pada setiap keadaan atau hambatan disebut dengan resilience. Menurut (Utami \& Helmi, 2017), resiliensi adalah kemampuan siswa untuk mananggapi dan memberikan solusi atas permasalahan yang sedang terjadi dalam berbagai keadaan. Resiliensi yang berkaitan dengan matematika adalah resiliensi matematis. (Johnston-Wilder, Lee, Brindley, \& Garton, 2015), dengan kemampuan bertahan dalam berbagai kondisi, siswa akan mengenali zona tidak nyaman mereka, menghargai tantangan, mengontrol emosi, memilih suatu tindakan, dan menggunakan ideide belajar yang tangguh ketika menghadapi kesulitan.

Oleh karena itu, setiap siswa perlu memiliki resiliensi matematis agar siap menghadapi setiap masalah atau keadaan yang terus berubah. (Lee \& Johnston-Wilder, 2017), menjelaskan bahwa dengan bantuan dari pihak luar dan terarah yang dilakukan oleh pelatih, siswa mampu menciptakan suasana belajar tangguh guna menghindari hambatan dan menciptakan ide-ide pemecahan masalah.

Empat indikator siswa memiliki kemampuan resiliensi matematis menurut (Hutauruk \& Priatna, 2017), adalah 1) matematika diyakini sangat berharga dan patut untuk dikuasai, 2) saat mendapat kesulitan tetap memiliki kemauan dan ketekunan belajar, 3) kepercayaan diri meningkat ketika mampu memahami matematika, 4) memiliki sikap tidak mudah menyerah dan memberikan kesan positif terhadap matematika.

Berdasarkan penelitian (Sari \& Untarti, 2021), (Hutauruk \& Priatna, 
2017), dan (Nurlita, 2015), kemampuan resiliensi dan berpikir kreatif matematis akan berbanding lurus. Dengan kemampuan resilensi yang tinggi, siswa dapat memunculkan semua jenis indikator berpikir kreatif. Selanjutnya, dengan tingkat resiliensi sedang siswa cenderung memunculkan sebagian indikator kemampuan tersebut. Rendahnya tingkat resiliensi membuat siswa kesulitan untuk memunculkan indikator yang diharapkan.

Menurut (Sari \& Untarti, 2021), berpikir kreatif adalah keahlian siswa untuk menciptakan berbagai ide dan gagasan baru untuk memecahkan sebuah masalah. Dengan pendapat yang sama (Eragamreddy, 2013) memaparkan jika pemikiran kreatif akan mengarahkan pada wawasan, pendekatan, perspektif, dan seluruh metode baru dalam memahami tentang kebaruan dan orisinalitas suatu hal. Menurut (Utami, Endaryono, \& Djuhartono, 2020), dengan kreatifitas, kemampuan berpikir akan digunakan secara maksimal untuk mendapatkan solusi atas masalah yang sedang dihadapinya. Dengan demikian, kemampuan berpikir seperti ini sebaiknya diajarkan kepada siswa sehingga siswa mampu menghadirkan ide berbeda yang dapat digunakan oleh mereka untuk mengatasi masalah nyata pada kehidupan mereka.

(Noer, 2011) menjelaskan ada 4 indikator berpikir kreatif yaitu: 1) fluency (berpikir secara lancar) yaitu siswa memiliki kemampuan untuk memberikan banyak jawaban atas masalah yang diberikan, menjelaskan banyaknya kemungkinan cara yang dapat digunakan, 2) flexibility (berpikir secara luwes) yaitu keahlian dalam memberikan variasi ide jawaban dengan melihat berbagai sudut pandang, 3) originality (berpikir secara orisinil) yaitu kecakapan siswa dalam menciptakan gagasan yang berbeda dan tidak dimiliki orang lain, menggunakan pendekatan yang berbeda dengan yang digunakan pada umumnya, 4) elaboration (berpikir memperinci) yaitu kemampuan siswa untuk memberikan gambaran secara detil tentang gagasan yang diberikan agar memberikan kesan menarik.

Berdasarkan penjelasan tersebut, penelitian berikut memiliki tujuan yaitu untuk mendeskripsikan atau mengetahui kondisi kemampuan siswa dalam menggunakan kreatifitasnya ditinjau berdasarkan tingkat resiliensi yang mereka miliki saat pembelajaran tatap muka terbatas. Adapun perbedaan dengan penelitian sebelumnya adalah proses pembelajaran dilakukan dengan tatap muka terbatas saat masa pandemi di mana jumlah siswa dibatasi dan waktu pembelajaran yang relatif singkat.

\section{METODE PENELITIAN}

Metode kualitatif digunakan untuk mendapatkan informasi secara rinci dan mendalam tentang kemampuan siswa dalam memikirkan cara baru dan berbeda dalam menjawab soal jika ditinjau berdasarkan ketahanan belajar matematika yang dimiliki oleh siswa.

Subjek pada penelitian yang dilakukan adalah 30 siswa kelas VII A SMP Negeri 1 Batu Ketulis tahun pelajaran 2020/2021. Kemudian, 30 siswa tersebut direduksi menjadi 6 orang siswa dengan cara purposive sampling. Selanjutnya, siswa mengisi angket untuk mengukur tingkat resiliensi matematis yang mereka miliki. Siswa dikategorikan menjadi 3 kelompok yaitu siswa yang memiliki tingkat resiliensi tinggi, tingkat resiliensi sedang, dan tingkat resiliensi rendah. Pengelompokkan ini dilakukan 
DOI: https://doi.org/10.24127/ajpm.v10i4.4194

dengan tujuan agar diperoleh informasi secara detail dan mendalam.

Terdapat tiga tahap dalam penelitian ini, ketiga tahapan penelitian ini akan dijelaskan yaitu: 1) tahap persiapan yaitu dengan mengidentifikasi masalah dan membuat instrumen penelitian, 2) tahap pelaksanaan yaitu turun ke lapangan dan mengumpulkan data dari subjek penelitian, dan 3) tahap pengolahan data yaitu menentukan kesimpulan dari hasil penelitian yang diperoleh.
Data dikumpulkan dengan cara pemberian angket, pemberian soal, dan wawancara. Adapun instrumen dalam penelitian ini berupa angket, tes, dan pedoman wawancara. Angket terdiri dari 20 pernyataan untuk mengukur resiliensi matematis siswa. Setiap pernyataan pada angket berisi 5 pilihan jawaban yaitu: sangat tidak sepakat (STS), tidak sepakat (TS), ragu-ragu (R), sepakat (S), dan sangat sepakat (SS). Penjelasan tentang angket disajikan dalam Tabel 1.

Tabel 1. Angket resiliensi matematis siswa

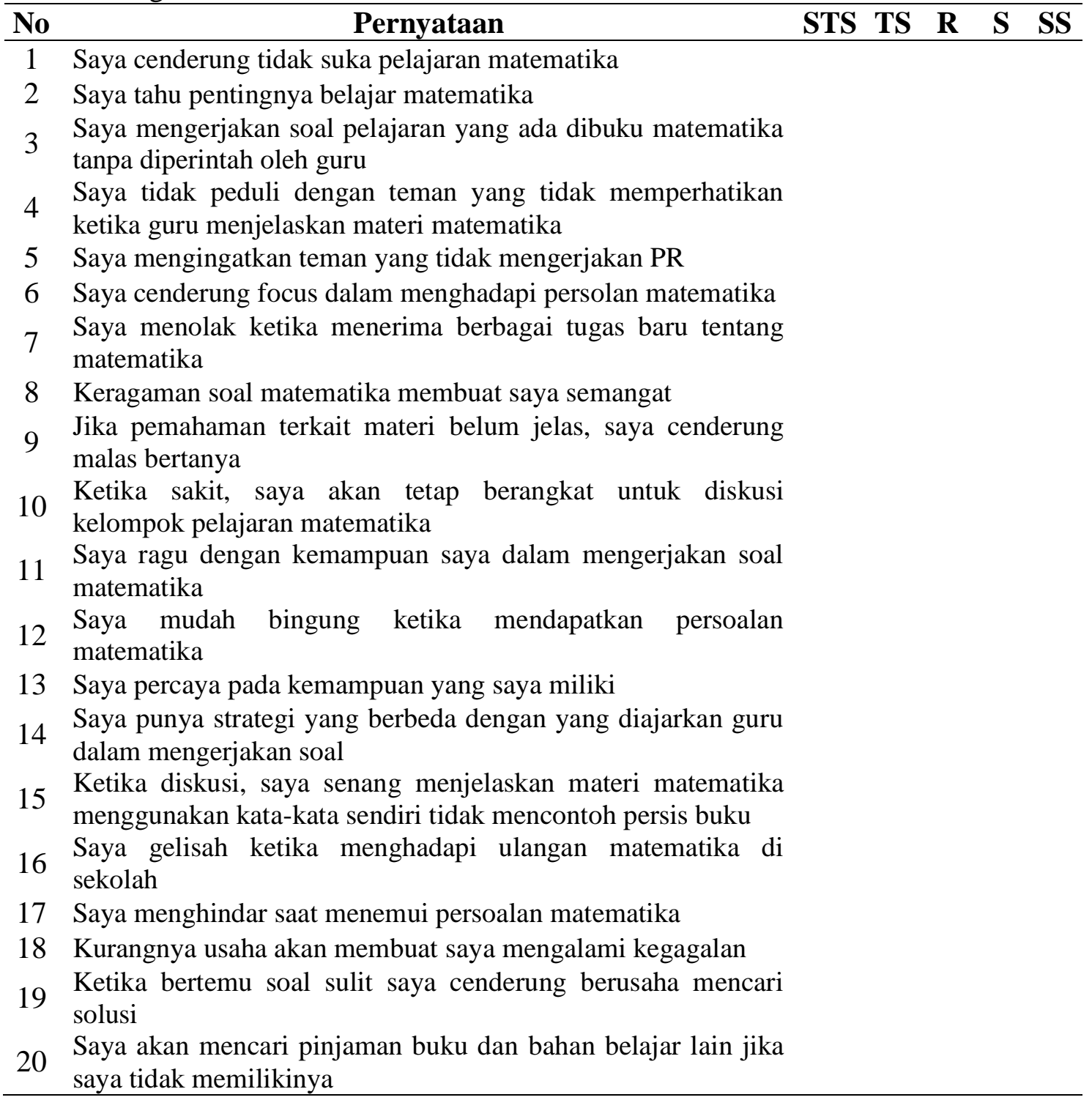


DOI: https://doi.org/10.24127/ajpm.v10i4.4194

Selanjutnya, menurut Ulfa (Kurnia, Royani, Hendriana, \& Nurfauziah, 2018), langkah pengkategorian skala resiliensi dihitung dengan menggunakan rumus sebagai berikut:

$$
\begin{aligned}
& M=\frac{1}{2}\left(N_{\text {max }}+N_{\text {min }}\right) \\
& S D=\frac{1}{6}\left(N_{\text {max }}-N_{\text {min }}\right) \\
& B_{b}=M-S D \\
& B_{a}=M+S D
\end{aligned}
$$

Keterangan:

$\begin{array}{lll}M & : & \text { Mean atau Rata-Rata } \\ S D & : & \text { Standar Deviasi } \\ N_{\max } & : & \text { Nilai Tertinggi } \\ N_{\min } & : & \text { Nilai Terendah } \\ B_{b} & : & \text { Batas Bawah } \\ B_{a} & : & \text { Batas Atas }\end{array}$

Kategori resiliensi dijelaskan dalam tabel 2 yaitu:

Tabel 2. Kategori resiliensi

\begin{tabular}{ccc}
\hline No & Batas Interval & Kategori \\
\hline 1 & $x<47$ & Rendah \\
2 & $47 \leq x<73$ & Sedang \\
3 & $73 \leq x$ & Tinggi \\
\hline
\end{tabular}

Instrumen kedua yaitu tes, berupa soal uraian terbuka (open-ended) terdiri dari 2 soal digunakan dalam menilai kondisi siswa dalam berpikir kreatif. selanjutnya, pedoman wawancara sebagai instrumen ketiga terdiri dari 10 pertanyaan berguna dalam menilai seberapa besar ketahanan siswa menghadapi berbagai kondisi untuk belajar matematika. Adapun pedoman wawancara dapat dilihat pada Tabel 3.

Tabel 3. Pedoman wawancara kemampuan berpikir kreatif

\begin{tabular}{cl}
\hline No & \multicolumn{1}{c}{ Pertanyaan } \\
\hline 1 & Bagaimana tanggapan kamu ketika menerima soal bangun datar tersebut? \\
2 & $\begin{array}{l}\text { Apakah kamu senang menjawab soal bangun datar menggunakan lebih dari satu } \\
\text { jawaban? Jelaskan? }\end{array}$ \\
3 & Apakah kamu menjawab soal dengan hasil pemikiranmu sendiri? \\
4 & Apakah kamu bisa mengerjakan soal dalam waktu yang relatif singkat? \\
5 & Ketika kamu kesulitan dalam menjawab soal bangun datar, apa yang kamu \\
& lakukan? \\
6 & Hal apa yang membuatmu kesulitan dalam menjawab soal bangun datar? \\
7 & Apakah kamu mamiliki lebih dari satu ide dalam menjawab soal ? \\
8 & Apakah kamu menjawab soal dengan rinci dan mendetil? \\
9 & Apa kamu punya cara tersendiri (berbeda dengan yang diajarkan guru) untuk \\
& menjawab soal bangun datar? \\
10 & Bagaimana tanggapanmu jika ada teman yang menggunakan cara yang sama \\
& dengan yang kamu gunakan?
\end{tabular}

Data dianalisis dengan cara di reduksi kemudian dilakukan penyajian data lalu diakhiri dengan penarikan sebuah kesimpulan dari data tersebut. Data direduksi secara terus menerus selama penelitian, data yang memiliki kaitan dengan berbagai indikator berpikir kreatif dikumpulkan dan data yang tidak memiliki kaitan dibuang. Data yang disajikan berupa teks naratif, tujuannya adalah untuk mempermudah dalam mendeskripsikan kemampuan berpikir kreatif siswa dengan berbagai tingkatan resiliensi siswa. Selanjutnya, proses akhir dari analisis data yaitu kesimpulan. 


\section{HASIL DAN PEMBAHASAN}

1. Hasil

Penelitian di SMP Negeri 1 Batu Ketulis pada semester genap tahun pelajaran 2020/2021 dilakukan dengan subjek 6 siswa kelas VII A. Sebelum tes, siswa diberikan angket untuk mengukur tingkat resiliensi matematis yang mereka miliki. Hasil angket siswa dipaparkan di Tabel 4.

Tabel 4. Hasil Angket Siswa

\begin{tabular}{cccc}
\hline No & Siswa & Skor & $\begin{array}{c}\text { Kategori } \\
\text { Resilience }\end{array}$ \\
\hline 1 & AT1 & 85 & Tinggi \\
2 & AT2 & 70 & Sedang \\
3 & AS3 & 57 & Sedang \\
4 & AS4 & 63 & Sedang \\
5 & AR5 & 39 & Rendah \\
6 & AR6 & 45 & Rendah \\
\hline
\end{tabular}

Berdasarkan Tabel 4, diperoleh hasil yaitu kelompok siswa dengan resiliensi matematis tinggi terdiri dari satu orang yaitu AT1, tiga orang dengan tingkat resiliensi sedang yaitu AT2, AS3 dan AS4, dan dua orang dengan tingkat resiliensi rendah AR5 dan AR6.

\section{Deskripsi Kemampuan Berpikir Kreatif pada tingkat Resiliensi Tinggi}

Sebelum membahas hasil tes siswa, terlebih dahulu akan disajikan soal nomor 1 yang digunakan dalam penelitian yaitu sebagai berikut:

"Gambarlah bangun datar yang memiliki keliling minimal $30 \mathrm{~cm}$ dan luas maksimal $60 \mathrm{~cm}^{2}$ yang terdiri atas gabungan dari beberapa bangun datar yang kamu ketahui. (Berikan contoh gambar sebanyak mungkin)"

Selanjutnya, jawaban soal nomor 1 dari AT1 dapat dilihat pada Gambar 1.



Gambar 1. Hasil soal nomor 1 AT1

Gambar 1 menunjukkan bahwa siswa AT1 dengan resiliensi matematis tinggi mampu memberikan dua buah jawaban yang berbeda yaitu dengan cara menggabungkan beberapa persegi dan persegi panjang serta menuliskan penyelesaian masalah secara sistematis. Siswa AT1 mampu memunculkan indikator fluency. Berdasarkan hasil wawancara, siswa AT1 mengatakan bahwa ada beberapa kemungkinan jawaban yang bisa dipilihnya.

Indikator flexibility muncul pada tahap di mana siswa AT1 hanya mampu memberikan sebuah ide dalam menyusun penyelesaian dan melakukan perhitungan dengan benar. Ide atas jawaban-jawaban yang diberikan pada soal nomor 1 pada dasarnya sama, yang membedakan hanya panjang dan lebar persegi.

Indikator originality muncul karena jawaban yang diberikan siswa tidak sama seperti cara yang telah dijelaskan oleh guru. Selanjutnya, siswa AT1 mampu mengomunikasikan bagaimana menentukan luas gabungan dan keliling gabungan secara detil. Siswa AT1 menenentukan luas dan keliling diawali dengan menghitung panjang persegi dan lebar persegi terbesar. Hal ini menandakan bahwa siswa mampu memunculkan indikator elaboration. Selanjutnya, akan ditampilkan soal nomor 2 . 
DOI: https://doi.org/10.24127/ajpm.v10i4.4194

\section{"Pak Rudi ingin mendesain bangunan rumah barunya. Untuk mendesain rumah yang baik, ada beberapa faktor yang harus dipertimbangkan seperti: jumlah orang, ruang gerak, furniture, dan lain sebagainya. Adapun ukuran minimal untuk setiap ruang yang ideal disajikan pada tabel berikut:}

\section{Tabel Ukuran ruangan ideal}

\begin{tabular}{lcc}
\hline \multicolumn{1}{c}{ Ruangan } & Panjang $(\boldsymbol{m})$ & $\begin{array}{c}\text { Lebar } \\
(\boldsymbol{m})\end{array}$ \\
\hline Kamar tidur utama & 4 & 3 \\
Kamar tidur anak & 3 & 3 \\
Ruang tamu & 5 & 4 \\
Ruang makan & 3 & 2 \\
Dapur & 3 & 3 \\
Ruang keluarga & 4 & 3 \\
Kamar mandi & 2 & 2 \\
Gudang & 3 & 2 \\
Garasi kendaraan & 5 & 3 \\
\hline
\end{tabular}

Luas tanah yang dimiliki Pak Rudi adalah $96 \mathrm{~m}^{2}$ dengan panjang $12 \mathrm{~m}$ dan lebar $8 \mathrm{~m}$. Bantulah Pak Rudi untuk mendesain rumah barunya dan gambarkan desain rumahnya. (Berikan contoh desain sebanyak mungkin)"

Selanjutnya, jawaban pertama dan kedua siswa AT1 pada soal nomor 2 ada pada Gambar 2 dan Gambar 3.

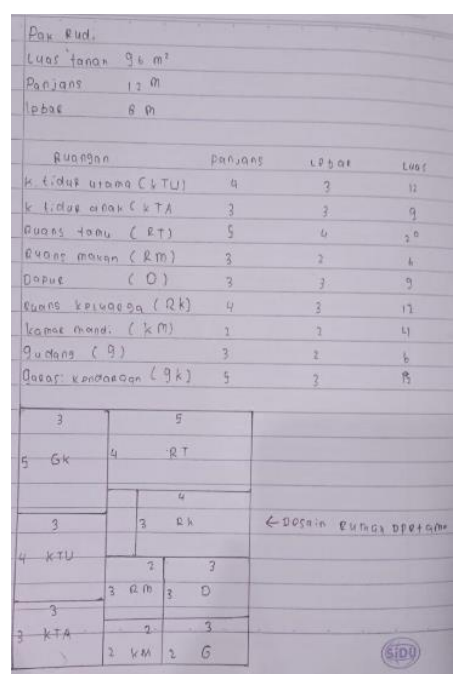

Gambar 2. Hasil pertama soal nomor 2 AT1

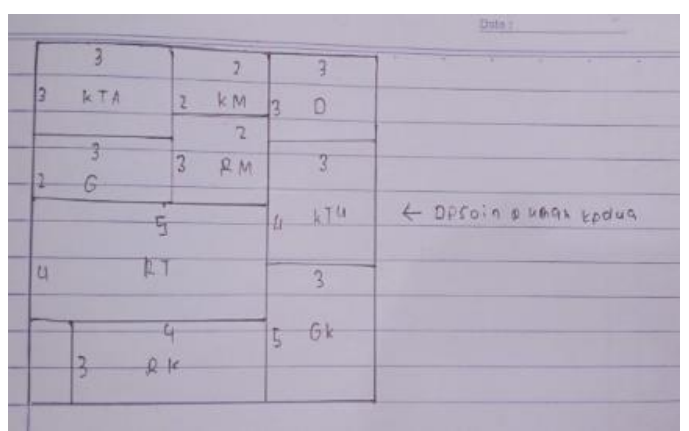

Gambar 3. Hasil kedua jawaban soal nomor 2 AT1

Gambar 2 dan 3 menunjukkan bahwa siswa AT1 mampu memunculkan indikator fluency dengan memberikan dua desain bangunan rumah yang berbeda. Indikator flexibility muncul tetapi tidak maksimal. Siswa hanya mampu memberikan sebuah ide dalam menyusun penyelesaian dan melakukan perhitungan dengan benar. Ide atas jawaban-jawaban yang diberikan pada dasarnya sama yaitu dengan mengelompokkan dan meletakkan ruangan dengan lebar $3 m$ seperti kamar tidur utama, kamar tidur anak, garasi kendaraan, dan dapur pada bagian samping rumah.

Indikator originality tidak muncul karena jawaban yang diberikan oleh siswa AT1 sama dengan cara yang diajarkan oleh guru. Selanjutnya, siswa AT1 mampu memberikan informasi desain bangunan rumah dengan sangat rinci di mana pemenpatan ruangan telah memenuhi persyaratan yaitu ukuran panjang rumah $12 \mathrm{~m}$ dan lebar rumah $8 \mathrm{~m}$. Sehingga, siswa AT1 dikatakan dapat memunculkan indikator elaboration.Siswa AT1 dapat memunculkan semua indikator dan Indikator yang sering muncul pada siswa dengan resiliensi tinggi adalah fluency dan elaboration. 
DOI: https://doi.org/10.24127/ajpm.v10i4.4194

\section{Deskripsi Kemampuan Berpikir Kreatif pada tingkat Resiliensi Sedang}

Jawaban dari soal nomor 1 oleh siswa AT2 dapat dilihat pada Gambar 4.

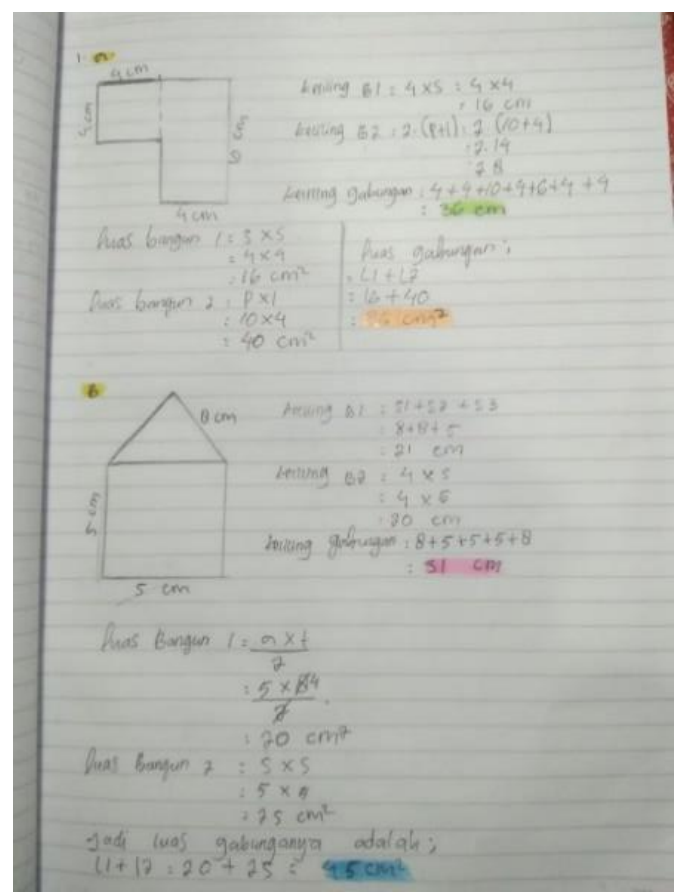

Gambar 4. Jawaban AT2 pada Soal Nomor 1

Berdasarkan Gambar 4, siswa yang memiliki tingkat resiliensi sedang dapat memunculkan indikator fluency. Siswa AT2 mampu memberikan dua jawaban berbeda dengan menyajikan gabungan antara beberapa persegi dan persegi panjang dalam jawaban pertama serta gabungan bangun datar persegi dan segitiga pada jawaban kedua. Siswa AT2 menuliskan jawabannya secara sistematis dengan menghitung terlebih dahulu luas bangun datar penyusun, kemudian menghitung keliling dengan menjumlahkan panjang garis penyusun bangun datar gabungan. Indikator flexibility tidak muncul karena siswa AT2 hanya mampu memberikan sebuah ide dalam menyusun penyelesaian masalah dan melakukan beberapa kesalahan saat menuliskan jawabannya seperti salah menjumlahkan luas gabungan pada jawaban pertama serta salah dalam menghitung luas segitiga.

Jawaban yang diberikan oleh siswa AT2 sama seperti yang diajarkan oleh guru sehingga Indikator originality tidak muncul. Indikator elaboration muncul karena siswa AT2 mampu mengomunikasikan bagaimana cara menentukan luas gabungan dan keliling gabungan bangun datar dengan rinci walaupun masih terdapat beberapa kesalahan dalam perhitungan. Siswa AT2 menjelaskan bahwa keliling gabungan bangun datar bukan merupakan jumlah dari keliling bangun datar penyusunnya.

Selanjutnya, jawaban AS4 pada soal nomor 2 yang dipaparkan dalam Gambar 5.

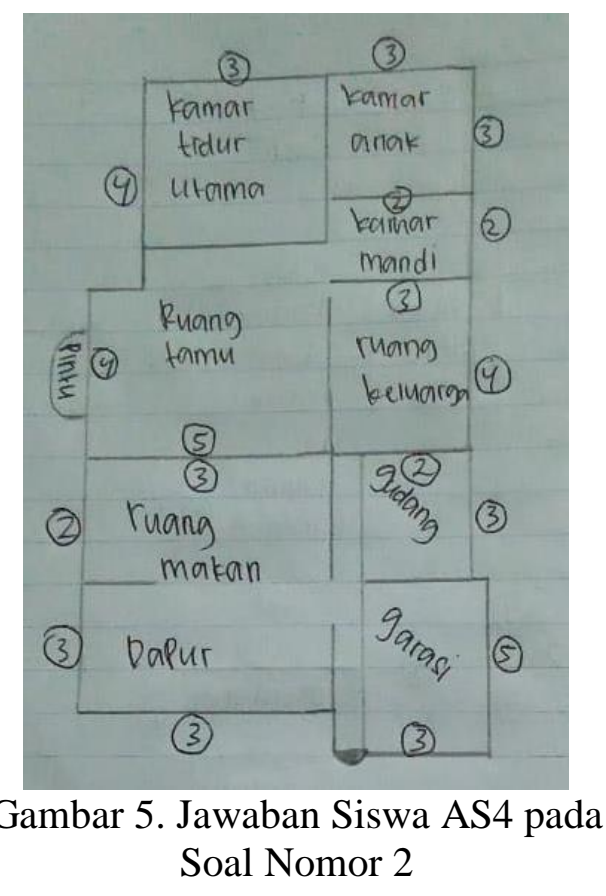

Siswa AS4 hanya mampu memberikan sebuah jawaban untuk soal nomor 2 dan jawaban yang diberikan siswa AS4 belum memenuhi syarat ukuran panjang dan lebar bangunan rumah yang diinginkan. Tidak ada indikator yang 
dimunculkan oleh AS4. Serupa dengan siswa AS4, indikator yang diukur juga tidak dimunculkan AS3. Berdasarkan hasil wawancara, siswa AS3 dan AS4 belum pernah bertemu dengan jenis pertanyaan serupa sehingga siswa merasa kebingungan untuk menuliskan jawaban dan pada akhirnya hanya menuliskan jawaban seadanya.

Berdasarkan uraian di atas, indikator yang dominan muncul dengan resiliensi matematis sedang adalah fluency. Siswa dapat memberikan beberapa jawaban namun ide matematis yang digunakan masih sama. Penyelesaian yang dituliskan sama dengan cara yang sudah pernah diajarkan oleh guru.

\section{Deskripsi Kemampuan Berpikir Kreatif pada tingkat Resiliensi Rendah}

Jawaban dari AR6 untuk soal nomor 1 disajikan dalam Gambar 6 .

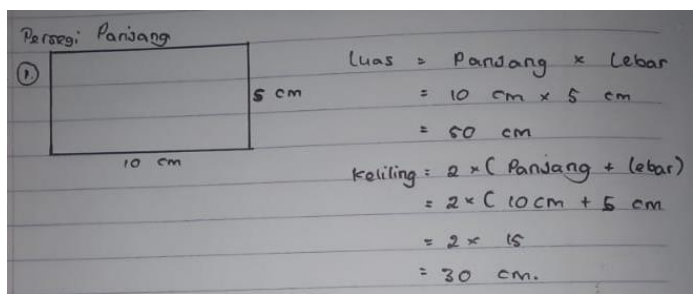

Gambar 6. Hasil soal nomor 1 AR6

Siswa AR6 hanya mampu memberikan sebuah jawaban yaitu soal no 1. Jawaban yang diberikan oleh AR6 memenuhi syarat bahwa keliling bangun datar minimal $30 \mathrm{~m}$ dan luasnya maksimal $50 \mathrm{~m}^{2}$, namun tidak memenuhi syarat yaitu merupakan hasil penggabungan dari beberapa jenis bangun datar.

kemampuan berpikir kreatif tidak muncul karena siswa AR6 belum mampu memberikan jawaban dengan benar.
Selanjutnya, jawaban AR5 untuk soal nomor 2 dapat dilihat pada Gambar 7.

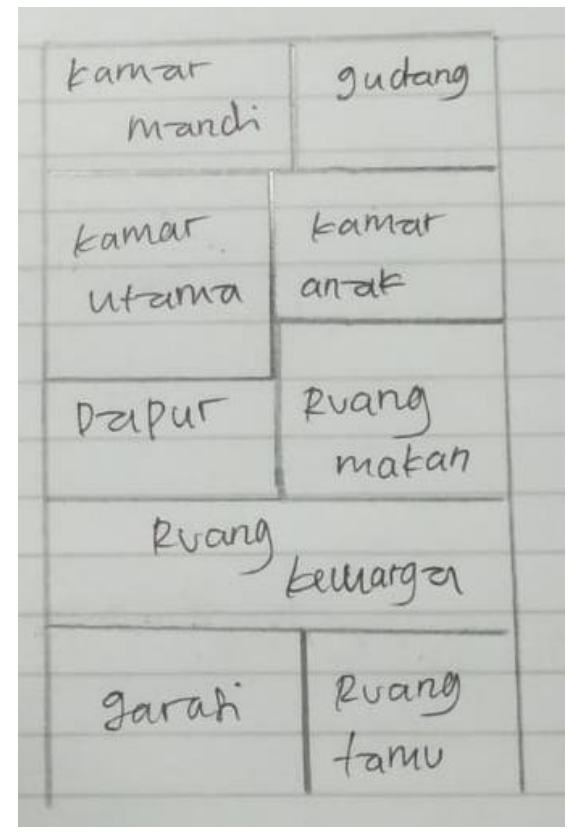

Gambar 7. Hasil Soal Nomor 2 AR5

Gambar 7 menunjukkan bahwa AR5 tidak dapat menyelesaikan soal nomor 2 sehingga indikator yang diukur tidak muncul. Siswa AR5 hanya mampu membuat desain rumah tanpa menggunakan syarat yang diberikan. Hal tersebut terjadi karena siswa AR6 salah dalam mengartikan makna soal.

Siswa beranggapan bahwa soal yang diberikan terlalu sulit karena kurangnya rasa percaya diri siswa untuk mengerjakan soal. Siswa juga merasa kebingungan dalam mencari alternatf jawaban, sehingga apa yang mereka tulis tidak memberikan solusi. Indikator berpikir kreatif tidak muncul karena jawaban yang diberikan siswa belum tepat.

\section{Pembahasan}

Setelah dilakukan analisis, diperoleh informasi yaitu siswa dengan resiliensi tinggi akan memunculkan semua indikator walaupun indikator 
DOI: https://doi.org/10.24127/ajpm.v10i4.4194

yang muncul belum sepenuhnya maksimal. Hal tersebut didukung oleh (Hutauruk \& Priatna, 2017), yang menyatakan bahwa siswa dengan resiliensi tinggi akan memunculkan semua indikator.

Indikator yang dominan muncul pada siswa dengan resiliensi tinggi adalah fluency dan elaboration. Menurut (Sari \& Untarti, 2021), siswa dengan resiliensi tinggi akan menciptakan berbagai variasi jawaban berbeda, memunculkan ide baru serta jawaban terperinci dan sistematis. Sesuai dengan pendapat tersebut (Nurlita, 2015), menjelaskan bahwa siswa dengan resiliensi tinggi dapat memunculkan indikator kelancaran dan keterincian.

Indikator yang paling sulit dimunculkan oleh siswa menurut (Sugandi, 2017), adalah indikator originality. Siswa sudah mampu memberikan beberapa jawaban berbeda dengan ide jawaban yang bervariasi, namun jawaban tersebut pada dasarnya masih sama seperti jawaban yang diajarkan oleh guru atau mengikuti contoh dari buku.

Berdasarkan hasil analisis, siswa dengan resiliensi sedang hanya mampu memunculkan sebagian indikator berpikir kreatif. Hal ini sesuai dengan (Habibah, Fathani, \& Nursit, 2021) yang menjelaskan bahwa siswa dengan tingkat resiliensi sedang hanya dapat memunculkan beberapa indikator dan umumnya bisa dikatakan sebagai siswa kurang kreatif. Indikator yang sering muncul adalah fluency. Siswa dengan kemampuan ini, sudah dapat menjawab soal secara sistematis, namun masih terdapat beberapa kesalahan saat melakukan perhitungan.

Menurut (Sari \& Untarti, 2021), kemampuan analisis yang dimiliki siswa belum sempurna sehingga tingkat ketelitian yang dimiliki oleh siswa dalam menjawab soal masih rendah. (Rahmatiyati \& Miatun, 2020) juga menyatakan pendapat yang sejalan yaitu siswa dengan tingkat resiliensi rendah akan kesulitan menjawab soal karena kurangnya ketelitian yang mereka miliki dan cenderung menyerah bila dihadapkan oleh soal yang sulit.

Siswa yang memiliki tingkat resiliensi seperti ini tidak menjawab soal dengan baik, hal ini sesuai dengan pendapat (Ansori \& Hindriyanto, 2020) yaitu siswa dengan resiliensi rendah akan menghadapi kendala dalam memahami dan menggunakan konsep dengan benar.

Menurut (Dilla, Hidayat, \& Rohaeti, 2018), siswa yang memiliki resiliensi rendah memiliki perasaan takut ketika mengerjakan soal sehingga siswa cenderung menuliskan jawaban seadanya dan tidak memiliki ketertarikan dalam menjawab soal. Menurut (Zanthy, 2018), siswa dengan resiliensi matematis rendah menanggap bahwa beban yang dirasakan merupakan sebuah ancaman sehingga mereka mudah mengalami keadaan frustasi

Salah satu kendala yang muncul dalam penelitian adalah kurangnya pengalaman siswa dalam menjawab soal terbuka atau open-ended mengakibatkan siswa tidak dapat memunculkan ide matematisnya secara optimal. Sebaiknya, siswa harus diberikan lebih banyak pengalaman mengerjakan soal terbuka atau open-ended.

\section{KESIMPULAN DAN SARAN}

Siswa dengan resiliensi tinggi mampu memunculkan semua indikator walaupun tidak semuanya mucul secara maksimal. Indikator yang paling sering muncul diantaranya adalah fluency dan elaboration. Indikator yang paling banyak dimunculkan oleh siswa dengan 
resiliensi matematis sedang yaitu fluency. Siswa dalam kategori ini mampu menuliskan beberapa alternatif jawaban namun masih menggunakan satu ide yang sama. Jawaban yang diberikan siswa masih mengikuti cara yang diberikan guru, sehingga siswa belum mampu mengomunikasikan pemikirannya secara rinci. Siswa dengan resiliensi matematis rendah tidak dapat memunculkan satupun indikator dengan maksimal karena siswa tidak memberikan jawaban dengan benar dan merasa bahwa soal yang diberikan masih terlalu sulit untuk dijawab.

Penelitian yang selanjutnya akan dilakukan, sebaiknya dapat mengaitkan kemampuan resiliensi matematis dengan kemampuan berpikir tingkat tinggi lainnya serta dapat menggunakan subjek yang lebih bervariasi seperti mengambil sample dari berbagai sekolah.

\section{DAFTAR PUSTAKA}

Ansori, A., \& Hindriyanto, Y. (2020).

Analisis Kemampuan Koneksi

Ditinjau Berdasar Pada

Kemampuan Resiliensi

Matematis. JKPM: Jurnal Kajian

Pendidikan Matematika, (5)2, 253-260.

Dilla, S. C., Hidayat, W., \& Rohaeti, E. E. (2018). Faktor Gender dan Resiliensi dalam Pencapaian Kemampuan Berpikir Kreatif Matematis Siswa SMA. IVET: Journal of Medives, 2(1), 129136.

Eragamreddy, N. (2013). Teaching Creative Thinking Skills. IJ ELTS: International Journal of English Language \& Translation Studies, 1(2), 124-145.

Habibah, S. U., Fathani, A. H., \& Nursit, I. (2021). Kemampuan
Berpikir Kreatif Matematis Berdasarkan Resiliensi Matematis Siswa. JP3, 16(9).

Hutauruk, A. J., \& Priatna, N. (2017). Mathematical Resilience of Mathematics Education Students. ICMSCE: International Conference on Mathematics and Science Education. doi:doi :10.1088/17426596/895/1/012067

Johnston-Wilder, S., Lee, C., Brindley, J., \& Garton, E. (2015). Developing Mathematical Resilience in School Students Who Have Experienced Repeated Failure. ICER.

Kemendikbud. (2021). Buku Saku Panduan Penyelenggaraan Pembelajaran Di Masa Pandemi Coronavirus Disease 2019 (Covid-19). Jakarta: Kemendikbud.

Kurnia, H. I., Royani, Y., Hendriana, H., \& Nurfauziah, P. (2018). Analisis Kemampuan Komunikasi Matematik Siswa SMP Ditinjau Dari Resiliensi Matematik. JPMI: Jurnal Pembelajaran Matematika Inovatif, 1(5), 933-940.

Lee, C., \& Johnston-Wilder, S. (2017). The Construct of Mathematical Resilience. United Kingdom: Elsevier.

Noer, S. H. (2011). Kemampuan Berpikir Kreatif Matematis dan Pembelajaran Matematika Berbasis Masalah Open-Ended. Jurnal Pendidikan Matematika, 5(1), 104-111.

Nurlita, M. (2015). Pengembangan Soal Terbuka (Open-Ended Problem) pada Mata Pelajaran Matematika SMP Kelas VIII. PYTHAGORAS: Jurnal Pendidikan Matematika, 10(1), 38-49. 
DOI: https://doi.org/10.24127/ajpm.v10i4.4194

Rahmatiyati, R., \& Miatun, A. (2020). Analisis Kemampuan Pemecahan Masalah Matematis Ditinjau Dari Resiliensi Matematis Siswa SMP. Teorema: Teori Dan Riset Matematika, 5(2), 187-202.

Sari, R. A., \& Untarti, R. (2021). Kemampuan Berpikir Kreatif Matematis dan Resiliensi Matematis. Mandalika Mathematics and Education Journal, 3(1), 30-39. doi:doi.org/10.29303/jm.v3i1.257 7

Sugandi, A. I. (2017). Meningkatkan Kemampuan Berpikir Kreatif Dan Resiliensi Matematis Siswa SMP Melalui Pendekatan Generatif. Jurnal Perspektif Pendidikan, 11(2), 67-77.

Utami, C. T., \& Helmi, A. F. (2017). Self-Efficacy dan Resiliensi: Sebuah Tinjauan Meta-Analisis. Buletin Psikologi, 25 (1), 54-65.

Utami, R. W., Endaryono, B. T., \& Djuhartono, T. (2020). Meningkatkan Kemampuan Berpikir Kreatif Matematis Siswa Melalu Pendekatan Open Ended. Faktor Jurnal Ilmiah Kependidikan, 7(1), 43-48.

Zanthy, L. S. (2018). Kontribusi Resiliensi Matematis Terhadap Kemampuan Akademik Mahasiswa Pada Mata Kuliah Statistika Matematika. Mosharafa, (7)1, 85-94. 